\title{
Protective Zone of an Industrial Plant as a Tool for Environmental Protection
}

\author{
Marta Przewocka ${ }^{1}$, Andrzej Greinert ${ }^{2, *}$, Jakub Kostecki ${ }^{2}$, Marta Skiba ${ }^{3}$, Anna Bazan-Krzywoszańska ${ }^{3}$ \\ ${ }^{1}$ Faculty of Civil Engineering, Architecture and Environmental Engineering, University of Zielona Góra, Poland \\ ${ }^{2}$ Department of Land Protection and Reclamation, University of Zielona Góra, Poland \\ ${ }^{3}$ Department of Architecture and Urban Planning, University of Zielona Góra, Poland
}

Copyright $(\subset 2015$ by authors, all rights reserved. Authors agree that this article remains permanently open access under the terms of the Creative Commons Attribution License 4.0 International License

\begin{abstract}
Many industrial investments may exert a significantly adverse impact on the natural environment. One of the methods used to limit the expansion of industrial pollutants is the creation of wooded protective zones around plants. One of the reasons for establishing a protective zone is the lack of practical possibility of satisfying the standards specified by the regulations. The case study has been based on the example of zone established around the Głogów Copper Smelter complex in the year 1987, covering an area of 2.84 thousand ha. In a consequence of the significant improvement of the state of forest- and agrocenoses in the closest vicinity of the enterprise, the Minister of Environment of the Republic of Poland, by virtue of the provisions applicable in the Act on Environment Protection Law, is able to eliminate the protective zone. Nevertheless the good idea is to leave the protective area development (i.e. forest), with a changed administrative-legal formula.
\end{abstract}

Keywords Protective Zone, Industrial Pollution, Copper Smelter, Law Regulations, Land Development

\section{Introduction}

Industrial plants, especially those associated with metallurgy and the production of metal components are large emitters of various pollutants, including metal-bearing dusts and gases. The dust emitted by copper smelters and copper processing plants contains excessive quantities of copper, lead, arsenic and cadmium (Ilic et al., 2011; Serbula et al., 2014). Many authors even consider these elements to be indicators of industrial pressure on the natural environment (Campa et al., 2008; Drab et al., 2011). Their occurrence at high concentrations in the air, water and soil for a long time is toxic for living organisms (Simonsen \& Scott-Fordsmand, 2004; Sims et al., 2009). Lacking any possibility of eliminating the environmental harmfulness of the plant, a protective zone is established around it, which is an operation whose legal origin in Poland is found in the Act of January $31^{\text {st }}, 1980$ on the Protection and Development of the Environment, which was repealed on October $1^{\text {st }}$, 2001. At present, such zones are created on the basis of the provisions of the Act of April 27 ${ }^{\text {th }}, 2001$ on Environment Protection Law. This legal act indicates the possibility of the organisation of limited use areas at the provincial level, or their inclusion in an industrial zone around environmentally harmful facilities. Since September 2014 - after the amendment of the Act on the Environment Protection Law, the right to adopt resolutions on the establishment of limited use areas around environmentally harmful facilities has been awarded to district councils.

The rules for the prevention and reduction of air pollution caused by emissions from industrial plants i.a. were specified in Directive 2003/35/EC of the European Parliament and of the Council of 26 May 2003. The directive includes the rule of prevention and caution and complements it with the concept of BATNEEC (Best available techniques not entailing excessive costs), which aims at optimisation of the adopted technology. Its interpretation is included in Directive No. 96/61/WE of the Council of the European Union on integrated pollution prevention and control (IPPC) of 24 September 1996. In 1996, Directive 84/360/EEC was superseded by the Integrated pollution prevention and control directive (IPPC), 96/61/EC, which applied the framework concept of Best Available Techniques (BAT) to the integrated control of pollution to the three media air, water and soil. The concept is also part of the directive's recast in 2008 (2008/1/EC) and its successor directive, the Industrial Emissions Directive 2010/75/EU published in 2010.

In Poland according to article 135 section 1 of the Environment Protection Law (the Journal of Laws of the Republic of Poland 2006, item 902 with subsequent amendments), if it results from an ecological audit or an evaluation of the environmental impact of an enterprise, required by the regulations act of 03 October 2008 (the Journal of Laws of the Republic of Poland 2008, No 199, 
item 1227 with subsequent amendments) Law on access to information on the environment and its protection, public participation in environmental protection and environmental impact assessments or a post-investment analysis that in spite of the use of available technical, technological and organizational solutions, environmental quality standards cannot be satisfied outside the premises of an industrial plant or another object, then a restricted use zone is established for a sewage purification plant, a communal waste dump, a composting plant, a communication route, an airport, a power line and plant as well as a radio communication, radio navigation and radiolocation installation. The lack of practical possibility of satisfying the standards specified by the regulations is one of the reasons for establishing a protective zone. In such a zone the negative environmental impact exceeds the standards of the acceptable negative environmental impact specified by separate regulations. In order to satisfy the EU regulations, it is necessary to specify the classification of pollution and to specify according to the Law on Environmental Protection of 27 April 2001 (the Journal of Laws of the Republic of Poland 2001, No62, item 627 , with subsequent amendments):

1. restricted use zones - art. 135 section 1 ;

2. introduction of integrated permissions in plants on the list of IPPC installations with specifications for modernization of installations used to reduce of pollution from technological processes art. $135 \mathrm{sec} .2$; 3. establishment of industrial zones in areas specified in local spatial development plans - art. 136a.

The Polish legal system is diffused. Thus, the legal acts refer to each other. This system in relation to the protection zones establishment involves merging the information from the three major acts, as it has been shown in Figure 1. A restricted use zone is established by a local legal act passed by a district council or a provincial assembly. This kind of law comes into force fourteen days after its announcement. Institutions establishing a protective zone specify:

1) zone boundaries,

2) restrictions in terms of land use,

3) technical requirements for buildings and the method of land use, which result from an evaluation of the environmental impact, a post-investment analysis or an environmental audit.

The aim of the paper is to analyse the functioning of the protective zone around the metallurgical enterprise, on the example of the Głogów Copper Smelter from the moment of its establishment in the year 1987 until its elimination in the year 2005. On this basis, the rationality of such a solution will be indicated in relation to the necessity of the protection of areas adjacent to other large industrial plants.

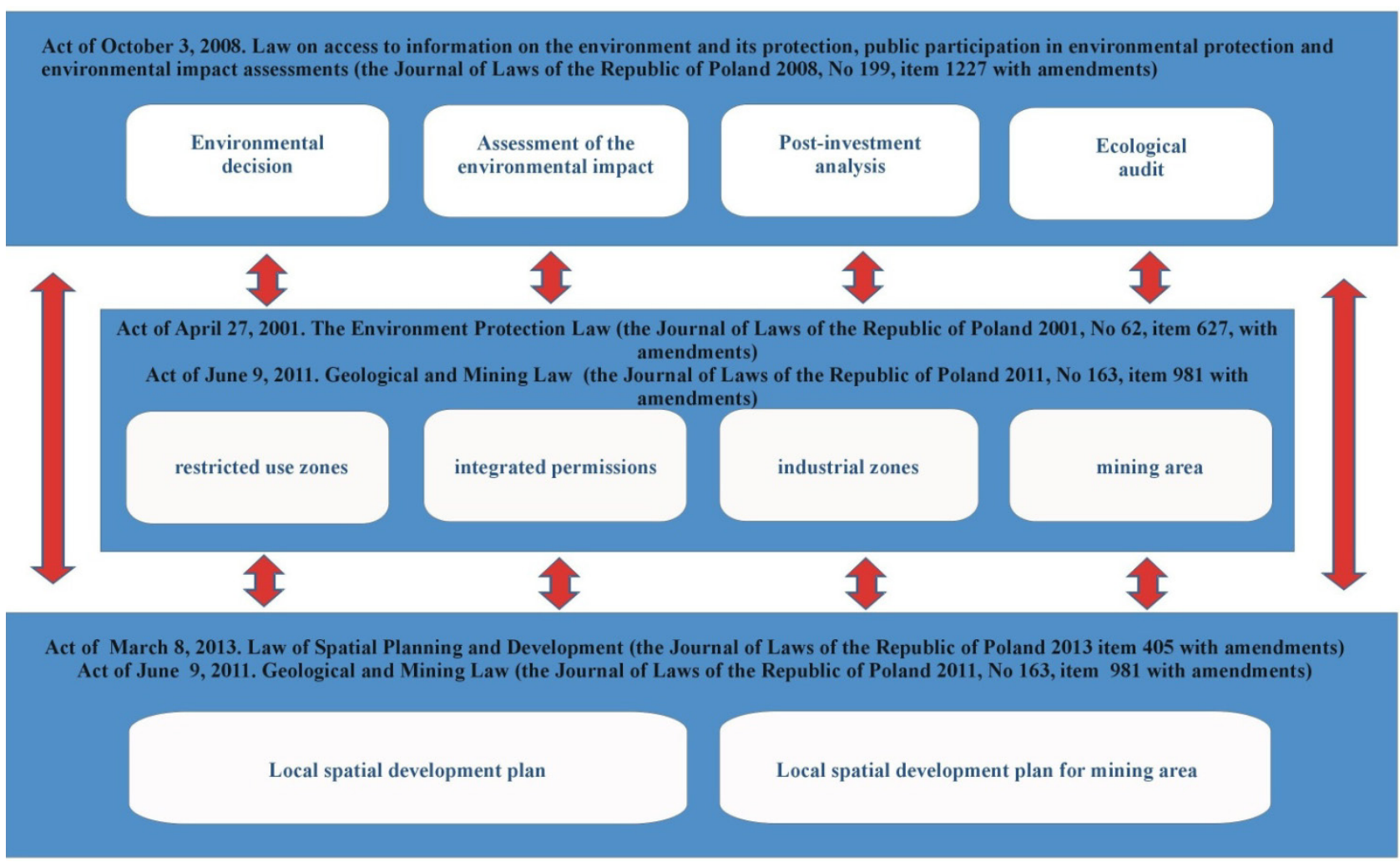

Figure 1. A diagram of interrelations between the regulations of the Polish law in terms of location of restricted use zones in spatial planning 


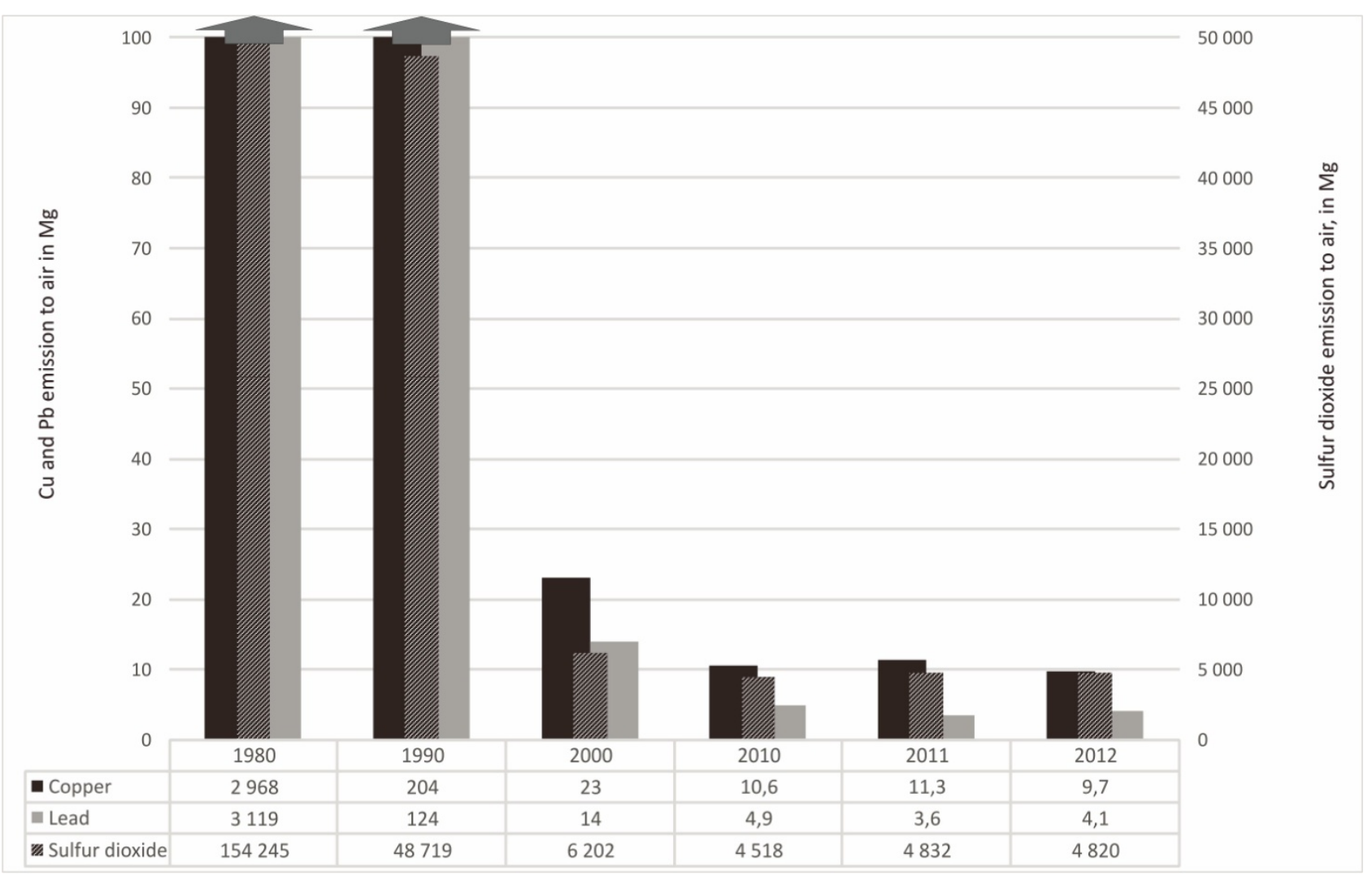

Figure 2. The total emissions of the divisions of KGHM Polish Copper SA in the years 1980-2012 (Mg)

\section{Case Study of the Glogów Copper Smelter}

The Głogów Copper Smelter is one of the largest industrial plants in Europe and the largest one in the metallurgical sector in Poland. The protective zone for this plant was created in the year 1987, when it had been noted that the environment cleanliness standards had been exceeded due to the negative impact of the smelter. The said operation was aimed at the elimination of the risk of the pollution of agrocenoses found within the space more remote from the plant. The emissions discharged from the Głogów Copper Smelter and other divisions of KGHM Polish Copper SA (located in the same region) over many years have had a great effect on the content of elements constituting environment pollution (Fig. 2), and on changes in the $\mathrm{pH}$ level of the soils adjoining the plant in its direct vicinity. As a consequence of the surface deposition, significant quantities of copper, lead, arsenic and cadmium were accumulated in the soil (Kostecki, 2010; Greinert et al., 2013).

Dust emission in the year 1980 amounted to $14,442 \mathrm{Mg}$, showing a significant decrease in the subsequent periods: $1990-2,017 \mathrm{Mg}, 2000-119 \mathrm{Mg}$ and $2005-179 \mathrm{Mg}$. A similar tendency is observed in relation to the emission of $\mathrm{SO}_{2}$, which is at the following levels (Fig. 2): $1980-154.2$ $\mathrm{Mg}, 1990-48.7 \mathrm{Mg}, 2000-6.2 \mathrm{Mg}$ and $2010-4.5 \mathrm{Mg}$ (GCSR, 2013). As a consequence of the deposition of copper-bearing dust, about $80 \%$ of the soils from the Głogów district is characterised by high content of copper.

\section{The Area Description}

The Głogów Copper Smelter is situated in Western Poland - 51 $41^{\prime} 15^{\prime \prime} \mathrm{N}, 15^{\circ} 58^{\prime} 36^{\prime \prime} \mathrm{E}$. According to Woś (1996), the area is located within the twenty third climatic region (Western Lower Silesia Region), in its north-eastern part bordering upon the Lubuskie Region (No. 14) and South Wielkopolska Region (No. 16). The region is located in the western part of the Silesian Lowland and Sudeten Foothills.

The construction of the first plant ("Głogów I") commenced in the year 1968, and production was launched in the year 1971. The "Głogów II" plant was built from the year 1974 onwards and its operation started in the year 1978 (GCSR 2013). Based on administrative decision No. UAN/R/8380/100/86/87 of November $25^{\text {th }}, 1987$, the protective zone for Głogów Copper Smelter I and II with an area of 2.84 thousand ha (Fig. 3) was established. The decision specified the general directions for the development of the zone, as well as the subsequent amendments made in the administrative decision of November $8^{\text {th }}, 2001$ based on which its area was reduced to 2,660 ha.

The protective zone covered 6 villages located within the area of 4 municipalities

- the lands of the Bogomice village, within the Kotla municipality,

- the lands of the Rapocin village, within the Głogów municipality,

- the lands of the Biechów and Wróblin Głogowski villages within the Głogów municipality, 
- partly, the lands of the Żukowice and Kłoda villages in the Żukowice municipality.

The described area is characterised by a moderate climate, with a significant impact of oceanic air masses. It is characterised by mild weather conditions, with significant variability of parameters. The average annual air temperature in the year 2013 was at a level of $9.4^{\circ} \mathrm{C}$, and the annual precipitation was at a level of $646.2 \mathrm{~mm}$ Winds from the western and south-western direction are prevalent (Report, 2013).

With regards to soil cover, the area around the Głogów I and Głogów II smelters is varied. In the south-eastern part of the protective zone (Dalków Hills) there are brown soils and luvisols formed from dust formations, deposited on sands and gravel, and in the northern part of the zone (Odra River Valley) alluvial soils, brown alluvial soils and humus alluvial soils with varied granulometric composition are present. In some places, the presence of other soils is observed: peat soils, muck soils, black earths, podzolic soils and even technosols (Kostecki, 2010). In terms of usefulness for agricultural purposes, the soils form complexes from 1 (very good wheat complex) to 6 (poor rye complex). Grassland located outside the protective zone occupies poorer soils - complexes $2 \mathrm{z}$ and $3 \mathrm{z}$, called "average grassland" and "poor and very poor grassland".

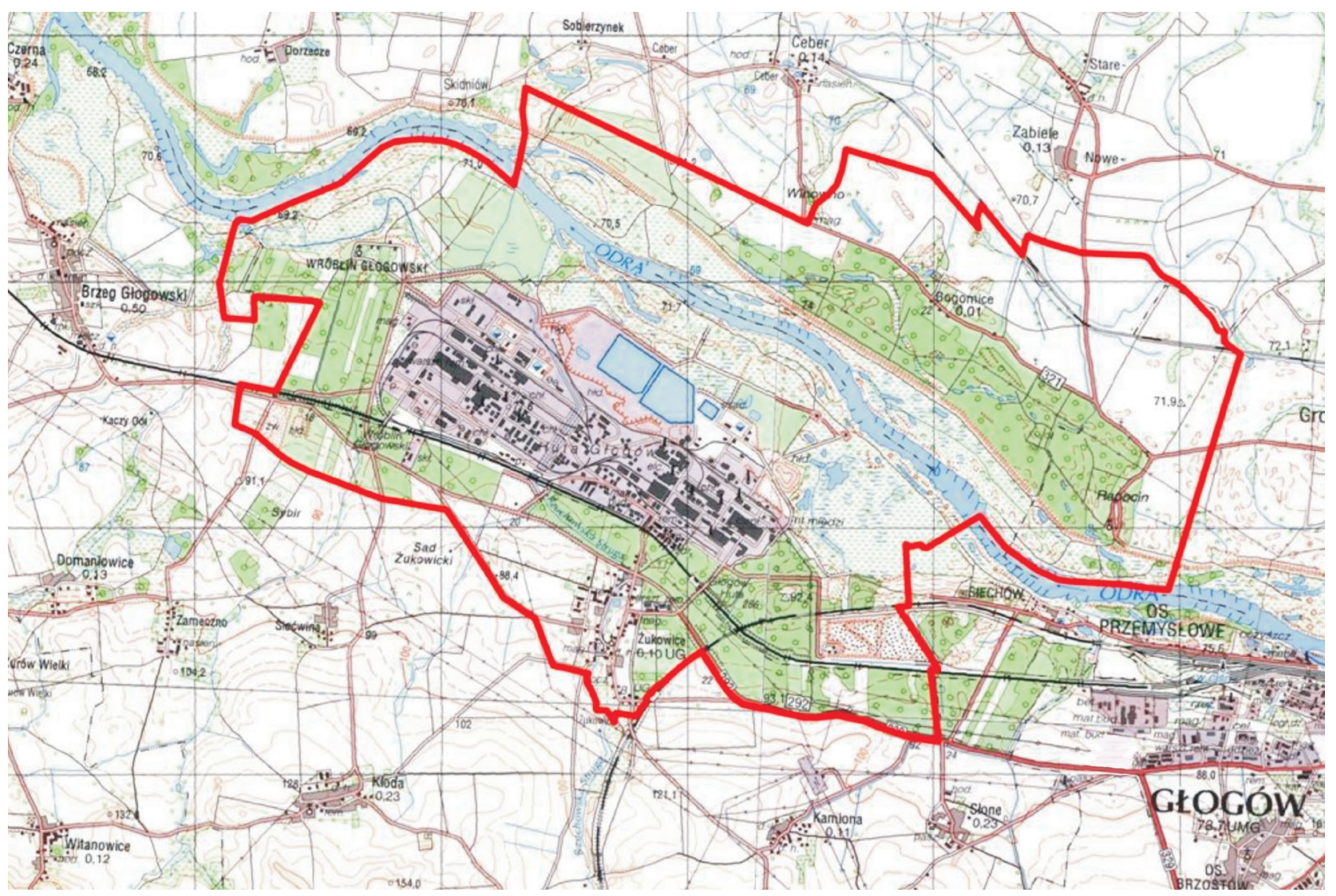

Figure 3. Location of the Głogów Copper Smelter within the area of the protective zone (border of the protective zone has been marked with red line) 


\section{The Protective Zone Development}

In accordance with the requirements specified in the decision which established the protective zone of the Głogów Copper Smelter, the protective zone development plan was approved on November $6^{\text {th }} 1990$, ZTE No. 40-25-06 from the year 1988 and implemented by Biuro Projektów Przemysłu Metali Nieżelaznych BIPROMET in Katowice. The required method of zone development has been presented in table 1 .

Table 1. The method of protective zone development according to the draft of technical-economic assumptions (ZTE No. 40-25-06) from the year 1988

\begin{tabular}{|c|c|c|}
\hline No. & Specification & Area \\
\hline 1 & Area of the Głogów Copper Smelter I and II & 458 ha \\
\hline 2 & $\begin{array}{c}\text { Industrial areas (landfills, sewage treatment } \\
\text { plants etc.) }\end{array}$ & 81 ha \\
\hline 3 & Areas of service development & 54 ha \\
\hline 4 & Roads, railways, water & 282 ha \\
\hline 5 & Existing high greenery & 454 ha \\
\hline 6 & Existing low greenery & 477 ha \\
\hline 7 & Designed high greenery & 474 ha \\
\hline 8 & Designed low greenery & 45 ha \\
\hline 9 & Agricultural industrial crops & 515 ha \\
\hline & Total: & 2840 ha \\
\hline
\end{tabular}

With regards to the approved development plan, the decision was taken to make the Głogów Copper Smelter responsible for the proper development, maintenance and use of the area and all buildings located within the protective zone. The development plan established bans on:

- the permanent stay of persons within the protective zone (necessity of displacement),

- the erection of residential buildings and public utility buildings,

- the location of plot gardens as well as sport and recreational equipment,

- agricultural production (plant and animal production),

- the keeping of vegetable farms and orchards,

- medicinal plant cultivation,

- the harvesting of pasture and meadow swards,

- the grazing of livestock on grasslands.

In accordance with the decision, a provision was made to leave 515 ha of land for the use of farmers until the year 2000 under specific conditions:

- the detoxication and biological reclamation of land,

- the elimination of the production of plants intended for direct consumption,

- a ban on using straw as feeding stuff,

- the agricultural use of land for the needs of the alcoholic beverage industry or seed production

- the cultivation of papilionaceous plants for green manure
- subjecting the collected crops to laboratory tests,

- sale of the crops only for strictly specified purposes,

- preparation of designs for land reclamation and agricultural development.

A vast majority of the obligations imposed on the Głogów Copper Smelter in connection with the management of the protective zone was performed. All farms were bought out (87\% of the zone's area) and the population inhabiting the Biechów, Bogomice and Rapocin villages was resettled. Attempts at obtaining the legal title to 9 farms in the Wróblin and Żukowice villages failed.

The former protective zone and the surroundings of KGHM belong to the Legnica-Głogów Copper Mining Area according to the local planning document - the Spatial Development Plan for the Lower Silesia Voivodship, as well as according to the strategic documents: A study of conditions and directions of spatial development of 25 May 2010 (act No. XLVIII/390/2010 by the Głogów City Council), and the Strategy for The Development of the Lower Silesia Voivodship until 2020 (including A Forecast of the Environmental Impact). In the abovementioned documents exploitation of copper and silver ore in the Legnica-Głogów Copper Mining Area, exploitation of lignite and different kinds of road and building stones and fireproof clays in the commune of Bogatynia (from the Rusko-Jaroszów deposit) as well as natural gas are regarded as the main mining industry. In the economic structure of the region this exploitation occupies a strategic position because it comprises over $50 \%$ of the country's deposits. The Legnica-Głogów Copper Mining Area has been included among intervention zones, which means that there occur particular phenomena or specific processes often connected with spatial conflicts (a monoculture area with advancing urbanization and changes to the environment) requiring intervention from the state.

The mining area and the smelter as well as the other plants are not surrounded by a protective zone or called a restricted use zone, which is specified by law as an area under the influence of a nearby industrial plant or a similar object. Depending on the source that influences a restricted use of real estate, we may deal with the influence of air quality, noise or an electromagnetic field.

The planning document which specifies the use of land on the premises of the smelter is A Study of Conditions and Directions of Spatial Development of the Town of Głogów of 25 May 2010, act No. XLVIII/390/2010 by the Głogów City Council. This land was approved for use by the metallurgical industry.

This document is currently being updated and a new project of A Study of Conditions and Directions of Spatial Development has been published. In both documents the premises of the smelter are regarded as an area of industrial activity of the smelter and are not included in the restricted use zone or the industrial zone. The premises of the Głogów Copper Smelter do not currently have a local spatial development plan. Such a plan is being prepared but it has 
not been published yet for procedural reasons.

\section{Economy within the Protective Zone}

Pursuant to the decision on the establishment of the protective zone and its development plan, the Smelter successively bought out the farms in the respective villages and then proceeded with the land development in accordance with the design. As part of the detoxication, all lands within the protective zone were subjected to liming treatment. The soil liming operation had already been started by the smelter in the 1980's, however. its intensification dropped in the 1990's Liming is one of the most well-known and often applied methods of the immobilisation of heavy metals (Alpaslan \& Yukselen, 2002; Greinert et al., 2013; Cui et al., 2014). The reason for this is its technological and technical simplicity and thus, low cost at relative effectiveness.

Also, biological reclamation of lands by the cultivation of plants, using the method known as green manure, was performed. For this purpose, the smelter, from the year 1991 till the year 1995 cultivated legumes, increasing the soil fertility on the purchased lands in the villages of Bogomice, Biechów, Wróblin Głogowski and Żukowice. Metals taken up by plants at that time are bonded for the time of their life biological sorption (Rosselli et al., 2003; Nouri et al., 2009; Kostecki, 2010; Lee, 2013). This type of cultivation also eliminates the possibility of the movement of the pollution together with the crops.

In the years 1991-1996, in cooperation with the Institute of Natural Fibres from Poznan and Przedsiębiorstwo Produkcji Celulozowo-Włókienniczej Cellinen sp. z o.o. in Radwanice, the smelter conducted experiments with crops of non-food industrial plants such as hemp and flax. Every year about 25 ha of flax and 50ha of hemp were grown for the purpose of harvesting straw which was processed by Cellinen. This is yet another frequently used method of dealing with areas demonstrating an excessive content of pollution in their soils. (Linger et al., 2002; Angelova et al., 2004). Owing to its application, the area does not lose productivity, while maintaining people's safety. From 1997 onwards, the smelter ceased to grow these plants due to the lack of demand for these raw materials.

In the northern part of the protective zone, about 515 ha of land remained in agricultural use. The land was leased by the Ceber Farm, which uses it in accordance with the requirements specified in the discussed decision based on the content of the concluded agreement. Part of the agricultural land in Żukowice remains in the possession of the Agricultural Property Agency (the former Żukowice State-Owned Farm). The date of agricultural use of 515 ha of land was set in the discussed decision until the year 2000. In the year 1991, the management plan for agricultural lands in the protective zone, which included the inventory of farms existing at that time, their structure and level of development was drawn up. The plan took into consideration the bans on keeping vegetable farms and orchards and meadows and pastures as a feeding stuff base for cattle were eliminated and methods of agricultural production, taking into account the conditions for carrying it out in the production zone, were developed. The crops obtained from the land parcels located within the protective zone were checked every year in terms of their pollution with heavy metals. The studied plants collected outside the protective zone did not show excessive contents of heavy metals in reference to the food and feeding stuff standards. For this reason, cattle breeding was reintroduced in the areas located within the outer belt from the year 2001 onwards. Breeding is kept under veterinary supervision by the University of Agriculture in Wrocław, with which the smelter concluded an agreement on the monitoring of the health of the breeding cattle in the area of the smelter. At the request of the smelter, by the decision of January $18^{\text {th }}$ 2001, the Department of Environment Protection of the Lower Silesia Provincial Office extended the date of agricultural use from the year 2000 till the year 2003. The decision also concerned the keeping of the buildings referred to in section 7 of the decision of November $6^{\text {th }} 1990$ until the year 2003. Further extensions of the dates of agricultural use of the described part of the zone's area until the year 2005 were obtained respectively.

At present, the buildings of the bought out villages of Bogomice, Rapocin and Biechów do not exist. The buildings were subjected to demolition, and the area was developed in accordance with the guidelines specified in technical-economic assumptions (afforestation or coverage with grass). Some of the buildings in the Żukowice village were leased for various activities, excluding the agricultural-food industry. The most recent lease agreement expired in the year 2004. According to the inventory, the total area of the planted land within the zone amounts to about 911 ha. Within the protective zone, the maintenance and cleaning work has been carried out by the NIRO company for several years. The scope of the work includes:

- manual and mechanical care for forest plantations,

- the maintenance of ditches and water courses within the protective zone,

- the maintenance of fire breaks,

- liming,

- redevelopment of the flood-bank,

- removal of deadwood and windbreaks,

- sanitary pruning in plantings,

- chipping after sanitary pruning and under power lines,

- complementation of the plantings,

- thinings of the plantings,

- cleaning of thickets,

- protection of trees against damage caused by animals.

In pursuance of the decision on the establishment of the protective zone, the monitoring of soils and underground waters was conducted on an annual basis. Control soil analyses were carried out at 50 permanent research points indicated by the University of Agriculture in Wrocław. The 
scope of analyses covered the determination of the content of heavy metals: copper, lead, zinc, arsenic and cadmium, as well as determination of the soil reaction. The results from the recent years show stabilisation of the studied environmental parameters, except the content of copper at several research points. The quality of underground water was controlled by a network of 17 piezometers, located on the border of the protective zone. The results of water analyses were sent each time to the Lower Silesia Provincial Office, Division in Legnica.

As a result of changes in the production technology, the emissions of pollution coming from the smelter were reduced significantly. Based on inspections performed by the Provincial Inspectorate for Environment Protection in Wrockaw, the conclusion was drawn that excessive impact on the environment does not go beyond the areas to which KGHM Polska Miedź S.A has the legal title. Owing to this, in the year 2001, the area of the protective zone was reduced by 180 ha, down to 2,660 ha. The zone was reduced from the south-east (land of the former Biechów village) based on decision No. Oś.Ie.III-6615/4/01 dated November $8^{\text {th }}, 2001$, issued by the Lower Silesia Province Governor. The land was provided to the Głogów city in order to establish an industrial district, which was determined by the Resolution of the City Council of February $19^{\text {th }} 2002$.

On May $4^{\text {th }} 2005$, the Lower Silesia Province Governor issued decision No. SR.V.6111/7/05 on the approval of the simplified forest management plan for the protective zone of the Głogów Copper Smelter, covering land with a total area of 911.65 ha drawn up for the period from January $1^{\text {st }} 2005$ to December $31^{\text {st }} 2014$. On this basis, the Forest Management and Geodesy Bureau - a Division in Brzeg asked the District Starosty in Głogów for the introduction of changes in the land and buildings register - from plantings "Lz" to forests "Ls".

On May $12^{\text {th }} 2005$, the Głogów Copper Smelter, based on the surveys conducted by the Lower Silesia Landscape Park Complex, filed a request with the Lower Silesia Province Governor to establish an ecological site situated in the inter-embankment area of the Odra River in the protective zone of the Głogów Copper Smelter, with a total area of 605.57ha. On October $28^{\text {th }} 2005$, the Lower Silesia Province Governor issued an order on recognition of the area under consideration as an ecological site.

On August $18^{\text {th }} 2005$, the Głogów District Governor introduced changes in the land and buildings register from plantings "Lz" to forests "Ls" for the area covered by the simplified forest management plan.

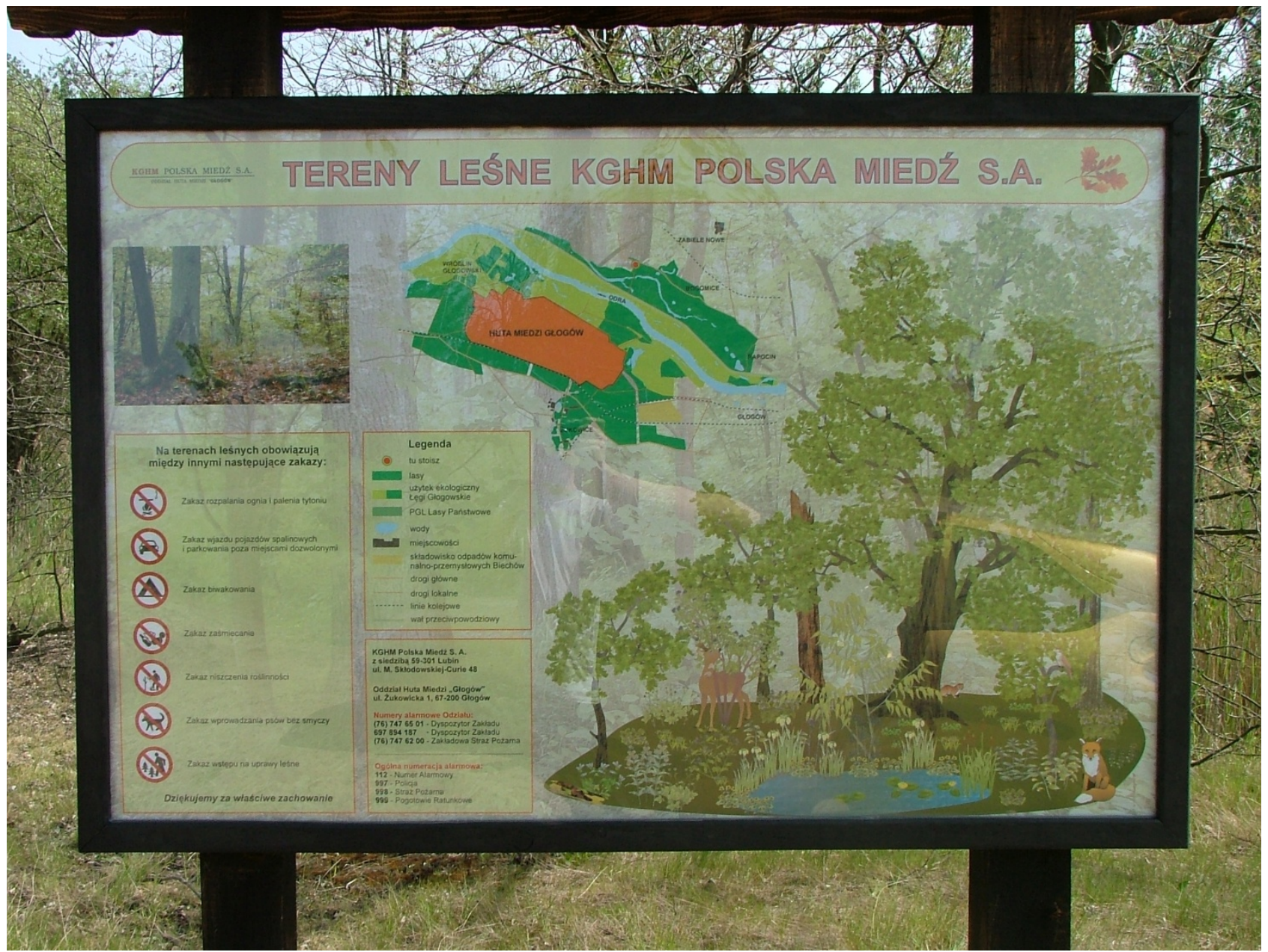

Figure 4. Information board in the area of the protective forest around the copper smelter 
Due to the significant improvement of the state of agrocenoses in the closest vicinity of the Smelter, on December $31^{\text {st }} 2005$, the Minister of Environment, by virtue of the provisions applicable in the Act on Environment Protection Law, eliminated the protective zone completely. At present, Głogów Copper Smelters I and II are surrounded by the protective forest from the former planting of the protective zone, with a changed administrative-legal formula and assumptions concerning its use. Free entry of people into the forest is possible, however, with some restrictions typical for this form of use. The entire area is provided with information boards (Fig. 4).

As a result of implementation into the Polish law of Directive 2010/75/UE by European Parliament and the Council of the EU of 24 November 2010 on industrial emissions (The Official Journal of the UE L 334 of 17 December 2010, pp. 17-119), on 01 January 2015 new regulations on integrated permissions and best available techniques will come into force.

\section{Conclusions}

- Production launched by the Głogów Copper Smelter in the year 1971 caused significant risk to the environment resulting from the emission of metal-bearing dust and gases.

- The protective tree cover zone has significantly limited the spreading of the pollution, however the natural content of heavy metals was observed in the soils beyond the protective zone. The reduction of emissions and the proper functioning of the protective zone led to its decrease and then its elimination, including the transformation of protective tree cover into forest land.

- The protective forest functions as the barrier against the spreading of the pollution from the smelter and is maintained in accordance with the provisions of the simplified forest management plan.

\section{Acknowledgements}

The paper was written within the framework of the research task for the participants of doctoral studies, financed from the funds of the earmarked subsidies for conducting scientific research or development work as well as tasks related to them in the year 2014, serving the purpose of the development of young scientists and participants of doctoral studies, financed in the internal competition mode (No. 5741/E-545/M/2014).

\section{REFERENCES}

[1] Act of July 11, 2014. The Environment Protection Law (the
Journal of Laws of the Republic of Poland 2014, item 1101, with subsequent amendments).

[2] Act of June 9, 2011. Geological and Mining Law (the Journal of Laws of the Republic of Poland 2011, No 163, item 981 with amendments).

[3] Act of March 27, 2003. Law of Spatial Planning and Development (the Journal of Laws of the Republic of Poland 2003, No 80, item 717, with subsequent amendments).

[4] Act of October 3, 2008. Law on access to information on the environment and its protection, public participation in environmental protection and environmental impact assessments (the Journal of Laws of the Republic of Poland 2008, No 199, item 1227, with subsequent amendments).

[5] Alpaslan B., Yukselen M.A., 2002. Remediation of lead contaminated soils by stabilization/solidification. Water, Air, and Soil Pollution 133, 253-263.

[6] Angelova V., Ivanova R., Delibaltova V., Ivanov K., 2004. Bio-accumulation and distribution of heavy metals in fibre crops (flax, cotton and hemp). Industrial Crops and Products 19, 197-205.

[7] Campa A.M.S., de la Rosa J.D., Sanchez-Rodas D., Oliveira V., Alastuey A., Querol X., Gomez Ariza J.L. 2008. Arsenic speciation study of PM2.5 in an urban area near a copper smelter. Atmos Environ 42, 6487-6495.

[8] Charzyński P., Bednarek R., Greinert A., Hulisz P., Uzarowicz Ł., 2013. Classification of technogenic soils according to WRB system. Soil Science Annual, 64 (4), 145-150.

[9] Council Directive 84/360/EEC of 28 June 1984 on the combating of air pollution from industrial plants.

[10] Cui H., Zhou J., Si Y., Mao J., Zhao Q., Fang G., Liang J., 2014. Immmmobilization of $\mathrm{Cu}$ and $\mathrm{Cd}$ in a contaminated soil: one- and four-year field effects. J Soils Sediments 14, 1397-1406.

[11] Drab M., Greinert A., Kostecki J., Grzechnik M., 2011. Seed germination of selected plants under the influence of heavy metals. Civil and Environmental Engineering Reports 7, 47-57.

[12] GCSR - Głogów Copper Smelter and Refinery, 2013. KGHM Polska Miedź S.A.,

http://www.kghm.pl/index.dhtml?category_id=276\&lang=en (Accessed 15 November 2014).

[13] Greinert A., 2010. Selected heavy metals and their behaviour in urban soils versus soil quality standards. Environment Protection Engineering, 36 (1), 45-53.

[14] Greinert A., Fruzińska R., Kostecki J., Bednarz K., 2013. Possibilities of heavy metals available for plants determination in the soil of an industrial zone. Ecological Chemistry and Engineering A, 20 (2), 251-260.

[15] Greinert A., Kostecki J., Fruzinska R., Bednarz K., 2012. Mobility and phytoavailability of lead in urban soils. Proceedings of ECOpole 6 (1), 105-111.

[16] Ilic I., Bogdanovic D., Zivkovic D., Milosevic N., Todorovic B., 2011. Optimization of heavy metals total emission, case study: Bor (Serbia). Atmospheric Research 101, 450-459.

[17] Jamali M.K., Kazi T.G., Arain M.B., Afridi H.I., Jalbani N., 
Baig J.A., Niaz A., 2008. Effect of liming on the distribution of heavy metals in untreated industrial sewage sludge produced in Pakistan for the cultivation of Sorghum bicolor (L.). Environmentalist 28, 366-375.

[18] Kostecki J., 2010. The content of heavy metals in soils and Populus nigra leaves from the protective zone of the Głogów copper smelter, in: Environmental engineering III, ed. by L. Pawłowski, M. R. Dudzińska, A. Pawłowski. Taylor \& Francis Group, London, 391-395.

[19] Kostecki J., Greinert A., Drab M., Wasylewicz R., Szafraniec M., Stodulski G., Wypych M., 2015. The total content of nitrogen in leaves and wood of trees growing in the area affected by the Głogów Copper Smelter. Journal of Elementology 1, 137-148.

[20] Lee J.H., 2013. An Overview of Phytoremediation as a Potentially Promising Technology for Environmental Pollution Control. Biotechnology and Bioprocess Engineering 18, 431-439.

[21] Linger P., Müssig J., Fischer H., Kobert J., 2002. Industrial hemp (Cannabis sati a L.) growing on heavy metal contaminated soil: fibre quality and phytoremediation potential. Industrial Crops and Products 16, 33-42.

[22] Nouri J., Khorasani N., Lorestani B., Karami M., Hassani H., Yousefi N., 2009. Accumulation of heavy metals in soil and uptake by plant species with phytoremediation potential. Environ Earth Sci 59, 315-323

[23] OJL 102/15 - Directive 2006/21/EC of the European Parliament and of the Council of 15 March 2006 on the management of waste from extractive industries and amending Directive 2004/35/EC.

[24] OJL 156/17 - Directive 2003/35/EC of the European
Parliament and of the Council of 26 May 2003 providing for public participation in respect of the drawing up of certain plans and programmes relating to the environment and amending with regard to public participation and access to justice Council Directives 85/337/EEC and 96/61/EC.

[25] OJL 334/17 - Directive 2010/75/EU of the European Parliament and of the Council of 24 November 2010 on industrial emissions (integrated pollution prevention and control).

[26] Rosselli W., Keller C., Boschi K., 2003. Phytoextraction capacity of trees growing on a metal contaminated soil. Plant and Soil 256, 265-272.

[27] Serbula S.M., Ilic A.A., Kalinovic J.V., Kalinovic T.S., Petrovic N.B., 2014. Assessment of air pollution originating from copper smelter in Bor (Serbia). Environ Earth Sci, 71, 1651-1661.

[28] Simonsen V., Scott-Fordsmand J.J., 2004. Genetic variation in the enzyme esterase, bioaccumulation and life history traits in the earthworm Lumbricus rubellus from a metal contaminated area, Avonmouth, England. Ecotoxicology 13, 773-786.

[29] Sims I., Crane M., Johnson I., Credland P., 2009. Biomonitoring the environmental impact of atmospheric emissions from the Avonmouth zinc smelter, United Kingdom. Ecotoxicology 18, 961-970.

[30] WIOŚ in Wrocław, 2014. Air, in: Report on the state of the environment in the region. WIOS Wrocław, http://www.wroclaw.pios.gov.pl/pliki/raporty/2013/01_powi etrze.pdf (Accessed 5 November 2014) (in Polish).

[31] Woś A., 1996. Outline of the climate of Poland, Wydawnictwo Naukowe UAM, Poznan (in Polish). 